\title{
DIVERSITY OF PHYTOPLANKTON IN COASTAL WATER OF KUANTAN, PAHANG, MALAYSIA
}

\section{Normawaty Mohammad-Noor*, Siti Nor Rahaida Harun, Zainab Mat Lazim, Yukinori Mukai, Najma Tasnim Mohamad and Shahbudin Saad}

Institute of Oceanography and Maritime Studies, Kulliyyah of Science, International Islamic University Malaysia, Jalan Sultan Ahmad Shah, Bandar InderaMahkota, 25200 Kuantan, Pahang, Malaysia

Corresponding address: Institute of Oceanography and Maritime Studies, Kulliyyah of Science, International Islamic University Malaysia, Jalan Sultan Ahmad Shah, Bandar InderaMahkota, 25200 Kuantan, Pahang, Malaysia.

\begin{abstract}
A study on diversity of phytoplankton was carried out in the coastal water of Kuantan, Pahang, Malaysia. Eighteen samples of seawater were collected from six stations from September 2011 to March 2012. This study was aimed to identify phytoplankton, to determine the species abundance and diversity. Physico-chemical parameters such as $\mathrm{pH}$, salinity, temperature and dissolved oxygen were recorded. Based on light microscopy, 70 taxa composed of 63 species of diatoms and 7 species of dinoflagellates were identified. Bacteriastrum delicatulum, Chaetoceros spp., and Coscinodiscus spp., were found to be dominant almost at all stations. Some potential harmful species identified were Ceratium fusus, Prorocentrum micans and Chaetoceros sp. The highest cell density was $32 \times 10^{3}$ cells/L and the lowest was $7.9 \times 10^{3}$ cells/L at stations 3 and 5, respectively. Significantly high number of cell density was found during NEM compared to other monsoons.
\end{abstract}

\begin{abstract}
ABSTRAK Satu kajian mengenai kepelbagaian fitoplankton telah dijalankan di sekitar perairan Kuantan, Pahang, Malaysia. Lapan belas sampel air laut telah dikutip di enam stesen dari September 2011 hingga Mac 2012. Kajian ini bertujuan untuk mengenal pasti fitoplankton, menentukan kelimpahan dan kepelbagaian spesies. Fiziko-kimia parameter seperti $\mathrm{pH}$, saliniti, suhu dan oksigen terlarut telah direkodkan. Berdasarkan mikroskop cahaya, 70 taksa yang terdiri daripada 63 spesis diatom dan 7 spesis dinoflagellates telah dikenal pasti. Bacteriastrum delicatulum, Chaetoceros spp., dan Coscinodiscus spp., adalah dominan spesis di hampir semua stesen. Beberapa spesis potensi berbahaya yang dikenal pasti adalah Ceratium fusus, Prorocentrum micans dan Chaetoceros spp. Kepadatan sel tertinggi adalah $32 \times 10^{3}$ sel / L dan yang terendah adalah $7.9 \times 10^{3} \mathrm{sel} / \mathrm{L}$ di stesen 3 dan 5 masing-masing. Kepadatan sel yang tinggi adalah signifikan pada monson timur laut berbanding dengan monson lain.
\end{abstract}

(Keywords: Phytoplankton, seawater parameter, below surface water, harmful algal bloom, coastal water of Kuantan, light microscopy)

\section{INTRODUCTION}

Study of phytoplankton diversity in Malaysia has shown that species diversity varied depend on several factors such as the level of nutrient concentration, physico-chemical properties of the seawater and hydrodynamic of the sea waters of a particular area. Study in Pulau Jarak, Pulau Perak Sembilan and the Sembilan group of islands has reported on 69 species of phytoplankton from 17 genera [1], whereas in Langkawi Island, 106 species of phytoplankton from 29 genera have been reported [2] and in coastal area of Bachok, Kelantan, 51 species from 18 genera of phytoplankton have been recorded [3]. Study on phytoplankton is important because they serve as primary producer and play essential role in the marine food web. Thus, the level of species diversity can be used to indicate the quality of the environment. Kuantan coastal water is located facing South China Sea and many anthropogenic activities such as human settlements and recreational are built along the coast line. These activities will somehow affect the marine ecosystem nearby. Therefore, the aim of this study is to determine the diversity and the abundance of phytoplankton in Kuantan coastal water. Result of this study can be used as baseline data for future study particularly in developing and planning of Kuantan coastal area. 


\section{MATERIAL AND METHODS}

Study on phytoplankton was conducted at coastal area of Kuantan, Pahang, East Coast of Peninsular Malaysia (Figure 1). Phytoplankton samples were collected at 6 stations (Figure 1).

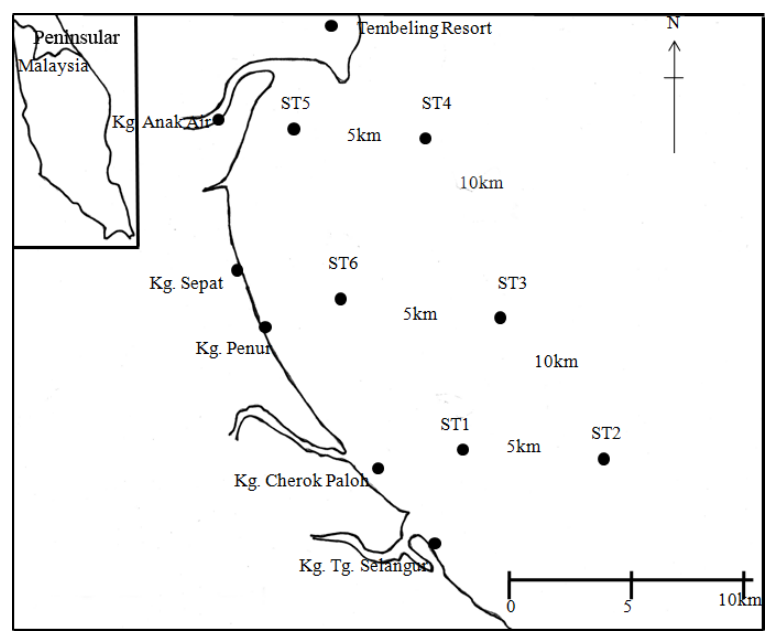

Figure 1 A map showing 6 sampling stations at Kuantan coastal water.

These stations were situated in 3 transects whereby each transect has 2 stations (Figure 1). The interval between each transect was $10 \mathrm{~km}$, meanwhile the interval between each station was $5 \mathrm{~km}$. Samples were collected once during southwest monsoon (SWM) (September 2011), northeast monsoon (NEM) (December 2011) and inter-monsoon (IM) (March 2011), respectively.

At each station, $10 \mathrm{~L}$ of phytoplankton samples were collected at $0.5 \mathrm{~m}$ below the sea surface by using Van Dorn Water Sampler and preserved immediately with Lugol's iodine. In the laboratory, these samples were concentrated into $50 \mathrm{~mL}$. Enumeration was done by counting $1 \mathrm{~mL}$ of sample using sedwick rafter cell under light microscope at magnification of 10x. For identification, phytoplankton samples were collected using plankton net of $20 \mu \mathrm{m}$ mesh in size. Phytoplankton species were identified by referring to Salleh and Tajuddin [4] and Hasle et al. [5] under light microscope with objectives of $40 \mathrm{x}$ and $100 \mathrm{x}$. Physico-chemical parameters such as temperature $\left({ }^{\circ} \mathrm{C}\right)$, salinity (psu), dissolved oxygen $(\mathrm{mg} / \mathrm{L})$ and $\mathrm{pH}$ were recorded using YSI 556 Multi-Probe System at the same depth where phytoplankton samples were collected.
To determine the diversity of phytoplankton, Shannon-wiener Index (H') and evenness were calculated. Analysis statistic such as one-way Analysis of Variance (ANOVA) was used to analyze the data.

\section{RESULTS AND DISCUSSION}

Seventy taxa of phytoplankton were identified belonging mainly to diatom with 63 genera and followed by dinoflagellates with 7 genera (Figures 2-6). There are several studies on phytoplankton diversity and abundance had been conducted in the east coast of Peninsular Malaysia. Study by Boonyapiwat [6] in the east coast of peninsular Malaysia and Gulf of Thailand has recorded 260 taxa with 55 genera of diatoms, 30 genera of dinoflagellates and two genera of blue green algae. In coastal area of Cukai, Terengganu, Shamsudin [7] had reported eight genera of dinoflagellates, four genera of blue green algae and seven genera of diatoms. While study done by Salleh and Ruslan [3] in the coastal area of Bachok Kelantan has recorded 20 genera of phytoplankton.

The most abundant diatom species found in all sampling stations were Bacteriastrum delicatulum, Chaetoceros spp. and Coscinodiscus spp. Study done by Boonyapiwat [6], Shamsudin [7] and Salleh and Ruslan [3] in several areas in east coast of Peninsular Malaysia also encountered high number of diatoms. However Shamsudin [7] also reported on the blooms of blue green algae in October 1993 in the coastal area of Cukai, Terengganu. This is supported by the earlier result found by Boonyapiwat [6] that there was high abundance of blue green algae near the coastal area in the east coast of Peninsular Malaysia. Several potential harmful species identified in this study were Chaetoceros spp. Ceratium fusus, Bacteriastrum comosom and Prorocentrum micans. 


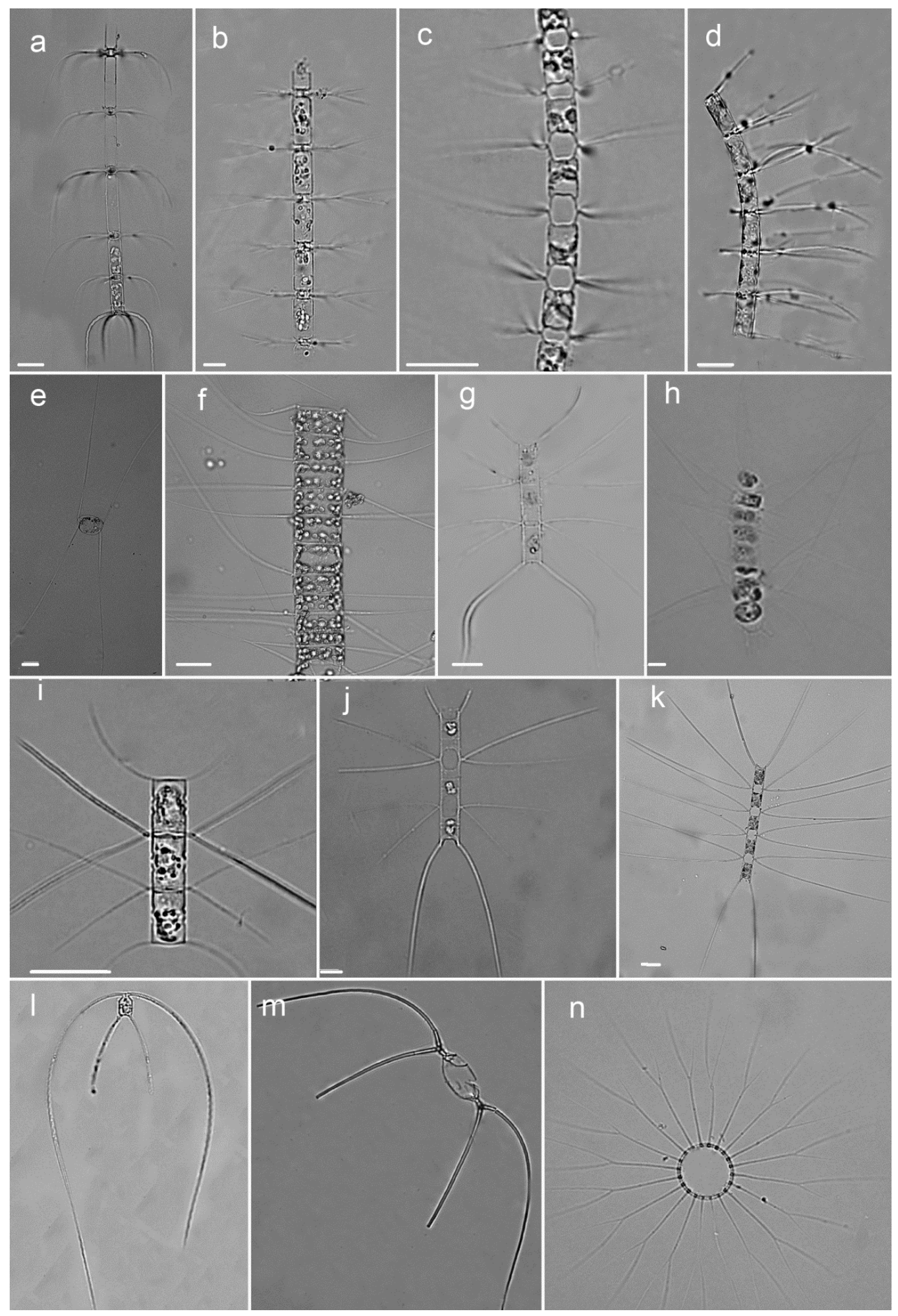

Figure 2. a. Bacteriastrum comosom; b. B. delicatulum; c. Chaetoceros distans; d. C. curvisetus; e. C. danicus; f. C. similis; g. C. affinis; h. C. constrictum; i. C. diversum; j. C. laciniosum; k. C. lorenzianum; 1. C. peruvianus; m. C. leave; n. B. hyalinum. Scale bar $=10 \mu \mathrm{m}$. 


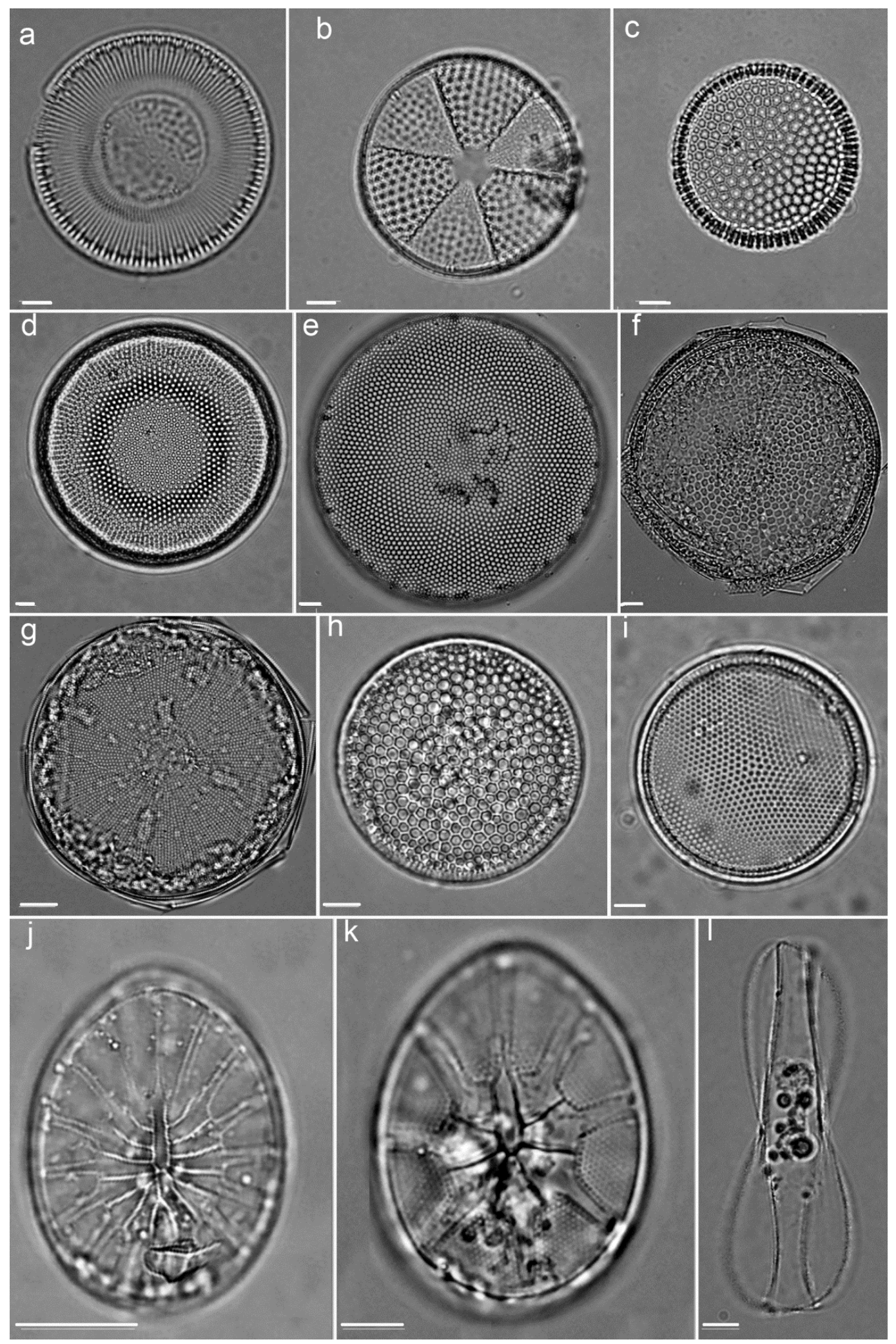

Figure 3. a. Cyclotella striata; b. Actinoptychus undulatus; c. Thalassiosira sp; d. Coscinodiscus sp.; e. Actinocyclus curvatulus; f. Coscinodiscus gigas; g. C. concinnus; h. C. nodulifer; i. C. excentricus; j. Asterolampra elegans; k. A. cleveanus; 1 Amphiproro gigantea var. sulcata. Scale bar $=10 \mu \mathrm{m}$ 


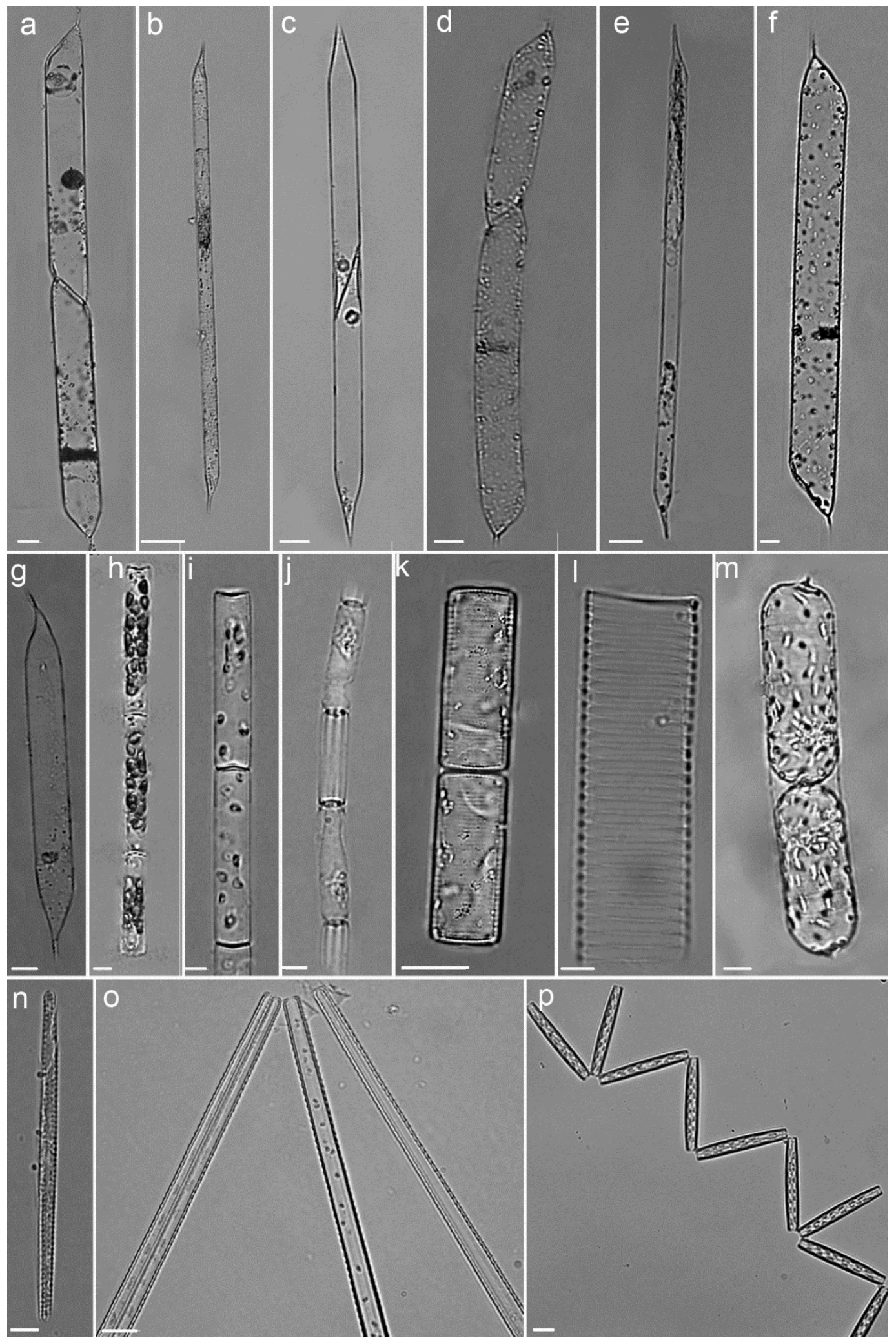

Figure 4. a. Rhizosolenia sp.; b. Proboscia alata; c. Rhizosolenia bergonii; d. R. clevei; e. R. imbricate; f. R. crassa; g. R. hebetate; h. Leptocylindrus danicus; i. L. minimus; j. Skeletonema costatum; k. Dactyliosolen antarticus; 1. D. blavyanus; m. D. fragilissimus; n. Thalassionema sp.; o. Thalassionema frauenfeldii; p. Thalassionema nitzschioides. Scale bar $=10 \mu \mathrm{m}$. 


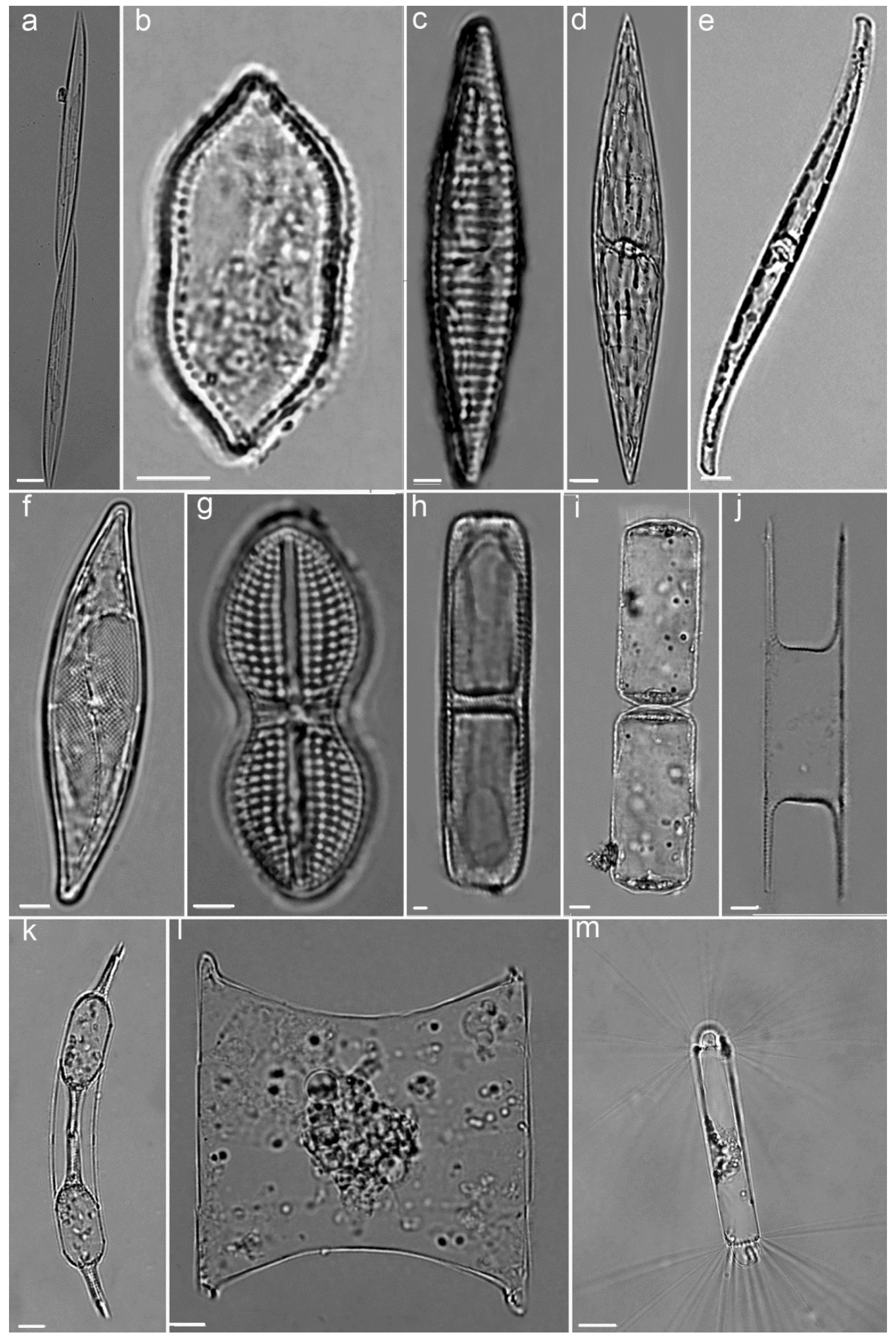

Figure 5. a. Pseudo-nitzschia sp.; b. Nitzschia panduriformis; c. Navicula transitrans f. delicatula; d. Pleurosigma directum; e. Nitzschia sigma; f. Pleurosigma naviculaceum; g. Diploneis didyma; h. Flagilariopsis cylindrus; i. Lauderia annulata; j. Hemialus hauckii; k. Hemialus indicus; 1. Hemialus membranaceus; $\mathrm{m}$. Corethron criophilum. Scale bar $=10 \mu \mathrm{m}$. 

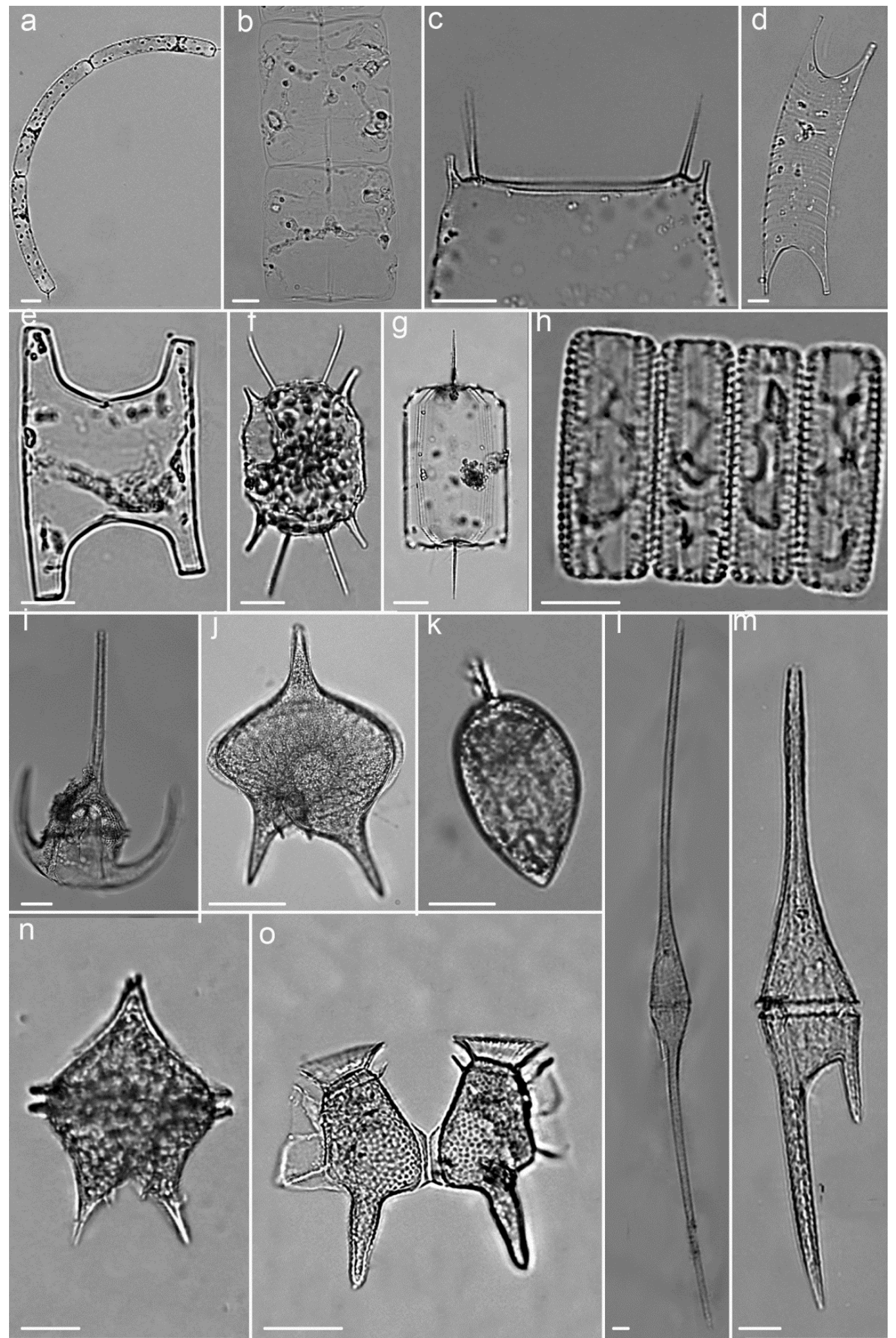

Figure 6. a. Guinardia striata; b. Meuniera membranacea; c. Odontella sinensis; d. Eucampia cornuta; e. E. zodiacus f. zodiacus; f. Odontella mobilensis; g. Ditylum sol; h. Flagilariopsis kergulensis; i. Ceratium tripos; j. Protoperidinium depressum; k. Prorocentrum micans; 1 . Ceratium fusus; $\mathrm{m}$. C. furca; n. Protoperidinium sp.; o. Dinophysis caudata. Scale bar $=10 \mu \mathrm{m}$ 
The highest cell density of phytoplankton was at station 3 with the value of $32 \times 10^{3}$ cells $/ \mathrm{L}$ and the lowest was at station five with the value of $7.0 \times 10^{3}$ cells/L (Figure 7).

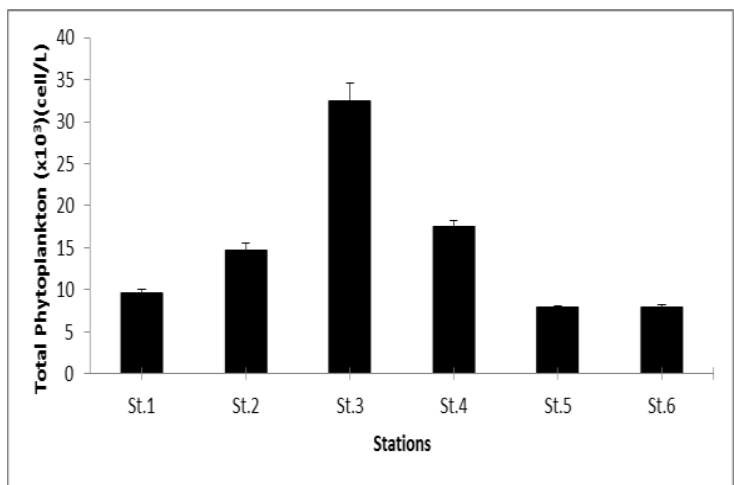

Figure $\mathbf{7}$ Total number of phytoplankton (cells/L) at each station.

These values were average values of three times sampling during different monsoons. However there was no significant different between stations $(\mathrm{p}<0.05)$ for phytoplankton cell density. Based on monsoon seasons, significant difference was found in NEM compared to SWM and IM. The highest cell density was recorded during NEM $\left(7.0 \times 10^{4}\right.$ cells/L) and the lowest was during IM $\left(8.3 \times 10^{3}\right.$ cells/L) (Figure 8).

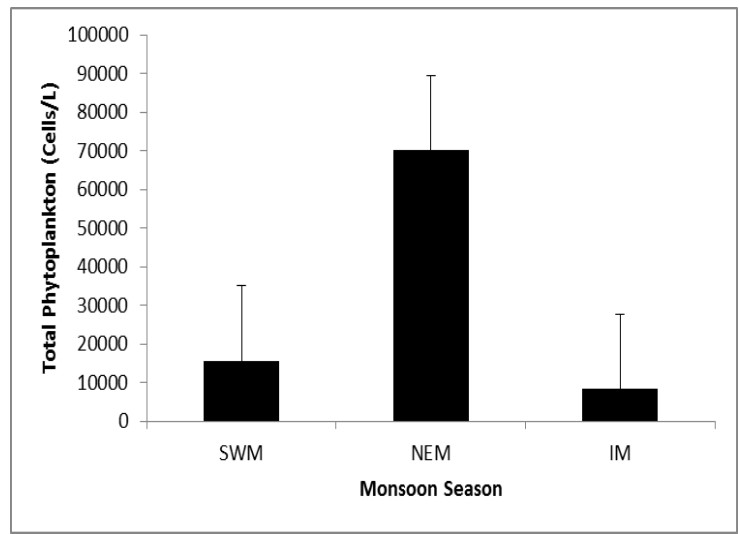

Figure 8. Total number of phytoplankton (cells/L) according to monsoon.
Phytoplankton abundance is affected by several factors including monsoon period [8], nutrient availability [9] and the hydrodynamic of the water. Slightly change in these factors can affect the productivity of phytoplankton [10]. Study on phytoplankton abundance during pre-monsoon and post-monsoon by Boonyapiwat [6] showed that the cell density recorded was different in both monsoons. Cell density was higher during pre-monsoon season compared to post-monsoon season. The highest value of Shannon $(\mathrm{H})$ was at station 5 with the value of 3.0 whereas the lowest was at station 3 with the value of 2.2. Station 3 has the highest abundance of phytoplankton but the lowest $\mathrm{H}$ value due to the high cell number Bacteriastrum and Chaetoceros. For evenness, stations 5 and 6 recorded the highest value (0.5) (Table 1).

Table 1. The diversity of phytoplankton based on Shannon-wiener Index (H'), Simpson Index and evenness at each station.

\begin{tabular}{lllllll}
\hline & St. & St. & St. & St. & St. & St. \\
& 1 & 2 & 3 & 4 & 5 & 6 \\
\hline Taxa S & 45 & 37 & 39 & 40 & 41 & 40 \\
& & & & & & \\
\hline Shannon & 2.9 & 2.3 & 2.2 & 2.7 & 3.0 & 2.9 \\
$\begin{array}{l}\text { Weiner, } \\
\text { H }\end{array}$ & & & & & & \\
\hline $\begin{array}{l}\text { Evenness } \\
\mathbf{e}^{\wedge} \mathbf{H} / \mathbf{S}\end{array}$ & 0.4 & 0.3 & 0.2 & 0.4 & 0.5 & 0.5 \\
\hline
\end{tabular}

Physico-chemical parameters recorded (temperature, salinity, dissolve oxygen and $\mathrm{pH}$ ) were within the normal range (Table 2).

Table 2. Physico-chemical data recorded at each station.

\begin{tabular}{lllllll}
\hline Parameters & St.1 & St.2 & St.3 & St.4 & St.5 & St.6 \\
\hline $\begin{array}{l}\text { Temperature } \\
\left({ }^{\circ} \mathrm{C}\right)\end{array}$ & $29.36 \pm 0.36$ & $29.17 \pm 0.23$ & $29.16 \pm 0.18$ & $29.37 \pm 0.28$ & $29.49 \pm 0.37$ & $29.58 \pm 0.42$ \\
$\begin{array}{l}\text { Salinity (psu) } \\
\text { Dissolved }\end{array}$ & $29.91 \pm 1.57$ & $29.66 \pm 1.14$ & $29.65 \pm 2.06$ & $30.03 \pm 2.05$ & $30.15 \pm 1.24$ & $29.93 \pm 1.90$ \\
$\begin{array}{l}\text { Oxygen } \\
(\mathrm{mg} / \mathrm{L})\end{array}$ & $4.67 \pm 2.53$ & $5.13 \pm 1.39$ & $5.53 \pm 1.70$ & $4.63 \pm 1.67$ & $4.59 \pm 2.05$ & $4.47 \pm 2.51$ \\
$\mathrm{pH}$ & $7.97 \pm 0.87$ & $8.17 \pm 0.70$ & $8.51 \pm 0.75$ & $8.50 \pm 0.29$ & $8.58 \pm 0.29$ & $8.51 \pm 0.35$ \\
\hline
\end{tabular}


Based on statistical analysis, there were no significant differences between these parameters and stations $(\mathrm{p}<0.05)$. The temperature recorded for all stations ranged between 29.08 to $29.53^{\circ} \mathrm{C}$. This is slightly lower than one recorded by Salleh and Ruslan [3] and Shamsudin [7]. In this study, the $\mathrm{pH}$ value recorded was from 7.97 to 8.58. The value measured was a little bit higher compared to $\mathrm{pH}$ recorded by Salleh and Ruslan [3] in coastal area of Bachok Kelantan (7.17 to 8.07 ) in the east coast of Peninsular Malaysia. $\mathrm{pH}$ is crucial in determine the growth rate of phytoplankton and therefore influenced phytoplankton abundance [11].

\section{CONCLUSION}

A total of 70 taxa which consists of 63 species of diatoms and 7 species of dinoflagellates were identified. Bacteriastrum delicatulum, Chaetoceros spp., and Coscinodiscus spp., were found dominant at almost all stations.

\section{ACKNOWLEDGEMENT}

Thanks to International Islamic University Malaysia (IIUM) for financial support (Grant EDW A 11-237-1028) and staff of Kulliyah of Science for field assistance.

\section{REFERENCES}

1. Salleh, A., Wakid, S.A., Bahnan, I.S. and Rahman, K.A.A. (2008). Diversity of phytoplankton collected during the Scientific Expedition to Pulau Perak, PulauJarak and the Sembilan Group of Island (SESMA). Malaysia Journal of Science. 27: 33-45.

2. Salleh, A., Wakid, S.A., Bahnan, I.S., Rahman, K.A.A and Nasrodin, S. (2005). Diversity of phytoplankton at Langkawi Island, Malaysia. Malaysia Journal of Science. 24: 43-55.

3. Salleh, A. and Ruslan, N.D. (2010). Phytoplankton composition and distribution in the Coastal Area of Bachok Kelantan. Malaysia Journal of Science. 29: 19-29

4. Salleh, A. and Tajuddin, Z. M. (2006).Phaytoplankton of Carey Island. $\left(1^{\text {st }}\right.$ Ed).Malaysia; Golden Hope
Plantation Berhad and Institute of Biological Sciences (UM). pp. 24-207.

5. Hasle, G. R., Syvertsen, E. E, Steidinger, K. A., Tangen, K., Throndsen, J. and Heimdal, B. R. (1997). Identification of Marine Phytoplankton. $\left(1^{\text {st }}\right.$ Ed). USA: Academic Press. pp.5-570.

6. Boonyapiwat, S. (1999). Distribution, Abundance and Species Composition of Phytoplankton in the South China Sea, Area I: Gulf of Thailand and East Coast of Peninsular

Malaysia.Proceedings of the First Technical Seminar on Marine Fishery Resources Survey in the South China Sea, Area I: Gulf of Thailand and East Coast of Peninsular Malaysia.24-26 November 1997, Bangkok, Thailand. pp 111-134.

7. Shamsudin, L. (1998). The Blue Green Algal Bloom in The Near shore waters of Cukai Bay Facing The South China Sea. Environmental Monitoring and Assessment. 59:123-134

8. Adam, A., Mohammad-Noor, N., Anton, A., Saleh, E., Saad., S., and Muhd-Shaleh, S. R. (2011).

Temporal and Spatial Distribution of Harmful Algal Bloom (HAB) Species in Coastal Water of Kota Kinabalu, Sabah, Malaysia.Harmful Algae.10:495-502

9. Mohammad-Noor, N., Sing, O.F., and Encik Anwar, E.W. (2012). Seasonal Distribution of Harmful Algal Bloom Species in East coast of Sabah Malaysia. Journal of Fisheries and Aquatic Science. 7: 431-438

10. Pradhan, V. and Shaikh, J.D. (2011). Seasonal fluctuation of plankton population correlated with physicochemical factors in Backwards of Jaikwadi Dam (Kaigaon). Journal of Chemical, Biological and Physical Sciences.1: 270-274

11. Hingga, K.R. (2002). Effects of $\mathrm{pH}$ on coastal marine phytoplankton. Marine Ecology Progress Series.238:281-300 